Chapman University

Chapman University Digital Commons

$10-2015$

\title{
Capomastro and Courier: Giacomo Borzacchi and Bernini's Equestrian Statue of Louis XIV in Transit
}

\author{
Karen J. Lloyd \\ Chapman University, lloyd@chapman.edu
}

Follow this and additional works at: https://digitalcommons.chapman.edu/art_books

Part of the Ancient, Medieval, Renaissance and Baroque Art and Architecture Commons, Other History of Art, Architecture, and Archaeology Commons, and the Sculpture Commons

\section{Recommended Citation}

Lloyd, Karen. "Capomastro and Courier: Giacomo Borzacchi and Bernini's Equestrian Statue of Louis XIV in Transit." In Making and Moving Sculpture in Early Modern Italy, edited by Kelley Helmstutler Di Dio, 191-205. Burlington, Vt: Ashgate Press, 2015.

This Book is brought to you for free and open access by the Art at Chapman University Digital Commons. It has been accepted for inclusion in Art Faculty Books and Book Chapters by an authorized administrator of Chapman University Digital Commons. For more information, please contact laughtin@chapman.edu. 
dern world, ry and new sals for both production ered in this architecture ious and/or i, ephemera m and non-

\title{
Making and Moving Sculpture in Early Modern Italy
}

\author{
Edited by
}

Kelley Helmstutler Di Dio 
nella distribuzione,

S.re harà caro che rdieri che hanno ri 200 a uno scarpellino osto, che se bene anche meno in rispetto del on ho voluto dichiarar ugnere o levare possa erano, dalla mano

I am currently

\section{Capomastro and Courier: Giacomo Borzacchi and Bernini's Equestrian Statue of Louis XIV in Transit}

Karen J. Lloyd
On February 24, 1684, Giacomo Borzacchi was given small iron pegs and wooden wedges by the members of the Fabbrica (Building Works) of St. Peter's, "which he needs for the armature that he is making for the horse and statue of the King of France."1 Borzacchi was a kind of handyman-a mason and engineer-who was in the regular employ of the Fabbrica for almost 30 years. His project in 1684, the "armature," must have been the wooden support structure needed to safeguard Gian Lorenzo Bernini's equestrian statue of French King Louis XIV on its long trip to Paris. The previously unpublished Fabbrica payment is the earliest dated indication of action being taken to start Bernini's horse on its journey from the artist's former studio at the Vatican, near the Santa Marta gate. Acting as a belated ambassador for Bernini, it was Borzacchi who accompanied the statue when it finally made its way to France in 1685.

Borzacchi's voyage to France with the equestrian Louis XIV was a modest echo of the pomp and circumstance of Bernini and his entourage in Paris 20 years earlier, yet we know little about this relatively humble individual and his trip. In his day-to-day work, Borzacchi was an essential, but largely unremarkable part of the creation of one of Rome's most spectacular monuments, St. Peter's. Accompanying Bernini's equestrian Louis XIV to France was a high profile role, which momentarily brought Borzacchi under the eyes of the French king and earned him international praise and a notable financial boost. The moment was, however, short-lived, and Borzacchi returned to his work among the largely anonymous craftsmen who performed the physical labor required to bring 'Bernini's Rome' into existence. ${ }^{2}$ Bernini's social and professional standing was remarkable, giving him a rank all of his own, as a kind of artist-prince. Over his lifetime he was able to amass a considerable fortune, and to secure respectable positions for his children. ${ }^{3}$ 
It seems to have been more difficult for most artists and craftsmen, individuals like Borzacchi and Bernini's main assistant Mattia de ${ }^{\prime}$ Rossi, to capitalize on all of the rewards that professional opportunities could bring to them. Their status was more fluid - they rose to the attention of royalty at times, and fell back to the humble wages and tasks of day laborers at others, their efforts to gain recognition blocked by middlemen and ministers. ${ }^{4}$ Looking further into the practicalities, problems and personalities that lay behind the scenes of early modern sculptural production provides an opportunity to gain a more nuanced understanding of the ranks of artists, artisans, and craftsmen who created Baroque Rome and represented it abroad.

Bernini's Louis.XIV was essentially completed by 1673 , although small changes continued to be made until 1677.5 It then remained in Bernini's Vatican studio for another eight years, long past the artist's death in 1680. No steps were taken to bring it to France until, as we have seen, early 1684. As Borzacchi was already gathering materials for the armature in late February, the practical process of moving the horse and rider must have begun by late January or early February of 1684 . The timing confirms that it was the Marquis de Louvois, who became the Superintendent of Building, Art and Factories after Jean-Baptiste Colbert's death in September 1683, who finally made progress in getting the horse moving.

On July 24, 1684, the Duc d'Estrées wrote to M. de Relingue to report that the day before the statue had been loaded onto a boat in Rome that would take it to the port of Fiumicino, in the first leg of its maritime journey. ${ }^{6}$ The statue left several days later, only to then get stalled at its next port of call, Civitavecchia, on orders from d'Estrées, who wished to hold things up until he received further information from the King. The reason for the additional delay is not clear. Roman avrisi suggested that the French feared run-ins with the Genovese. ${ }^{8}$ In fact, the boat sent by the French to retrieve the statue had been attacked on its way to Civitavecchia by a fleet of 37 Spanish ships. The French ship, Le Bon, and its escort had to retreat to Livorno for some time to recover. ${ }^{9}$ The French feared similar problems on the return trip, estimating that the voyage "would not be without much risk." ${ }^{\prime \prime 10}$ Meanwhile, D'Estrées mentioned in a letter that "it is no little job to put such a large contraption on a boat," and the logistics of packing and moving the statue were an on-going problem. ${ }^{17}$

Unlike the majority of Baroque equestrian statues, Bernini's was carved out of a single piece of solid marble. His biographers remarked upon the size of the stone and the sheer audacity of the undertaking, boasting that it was made out of the largest piece of marble ever seen in Rome. ${ }^{12}$ The statue measures in at 366 high $\times 364$ long $\times 150$ wide (in cm; approx. $12 \times 12 \times 5$ in ft). ${ }^{13}$ Borzacchi called in considerable reinforcements to move the sculpture, including borrowing an assortment of large metal pulleys, as well as fir and chestnut planks and beams, some of them over 25 feet long, from the Fabbrica. He later returned "two iron cases as well as the four metal pulleys, which served only at the Ripa to lower and embark the statue." ${ }^{\prime 14}$ Some of these were instruments that had been made for Domenico Fontana to move the Vatican obelisk to 
raftsmen, individuals Rossi, to capitalize on bring to them. Their alty at times, and fell $t$ others, their efforts ers. ${ }^{4}$ Looking further $y$ behind the scenes of tunity to gain a more and craftsmen who

1673, although small smained in Bernini's st's death in 1680. No : seen, early 1684. As ture in late February, nust have begun by firms that it was the of Building, Art and ser 1683 , who finally

igue to report that the me that would take it uney. ${ }^{6}$ The statue left of call, Civitavecchia, tit he received further al delay is not clear. rith the Genovese. ${ }^{8}$ In $\exists$ been attacked on its anch ship, Le Bon, and s.. "The French feared oyage "would not be $n$ a letter that "it is no ve logistics of packing

nini's was carved out ked upon the size of ting that it was made re statue measures in $x 5$ in $\mathrm{ft}){ }^{13}$ Borzacchi sculpture, including 1 as fir and chestnut he Fabbrica. He later s, which served only sse were instruments ı Vatican obelisk to its present location in front of St. Peter's; Borzacchi's use of Fontana's tools suggests the enormity of the task of moving the Louis XIV.15

Earlier equestrian monuments made for transport, such as Pietro Tacca's Henry IV (begun 1604), Philip III (begun 1606) and Philip IV (begun 1634), were produced in bronze. This facilitated shipping, as they could be cast in pieces that were then crated separately and assembled on arrival. Even so, the challenges were substantial (the statue of Henry IV weighed 13,095 lbs and was almost lost at sea), the risks were high, and the delivery times long. ${ }^{16}$ In executing his Louis XIV in marble-and in a single piece of marble no lessBernini showed a particular disinterest for the exigencies of shipment.

The French would encounter similar difficulties two years later in the process of shipping Domenico Guidi's History Writing the Deeds of Louis XIV $(1677-85) .{ }^{17}$ Like Bernini's equestrian, Guidi's monument to Louis XIV was made in marble and unwieldy-particularly as it stands at $2.9 \mathrm{~m}$ or over $9.5 \mathrm{ft}$ tall. Guidi apparently had his own way of packing the work ("ayant voulu la faire à sa mode"), in what Carlo Cartari described as "a spacious, and tall case."18 The French were suspicious of the projected expense, in particular for the crating; the cost alone of moving the statue from Guidi's studio to the Ripa Grande for embarkation was set at 300 scudi. ${ }^{9}$ De la Teuliere found himself in a bind: he wanted to get a second estimate about packing prices from someone trustworthy, but was wary of risking Guidi's anger should anything happen to the statue en route..$^{20}$ There were further problems with finding an appropriate boat, especially given the Tiber's low water level. Guidi's History ended up waiting at the port for 20 days (costing the French 3 scudi a day) as the French waited to receive two more statues, of Germanicus and Cincinnatus, to add to the shipment. ${ }^{21}$ The History couldn't be loaded until everything else intended for the shipment had arrived-in its crating it was apparently so big that it blocked anything else from being put onto the boat. $^{22}$ De la Teulière's frustration with the whole process burst through at the end of his letter to Louvois, as he griped: "I do not believe that there are more stubborn people in the world than the people of this country [Italy] on the occasions when they think that you cannot do without them." ${ }^{23}$ A certain "Morelli" - likely Giovanni Battista, a member of Guidi's studio-"and his companion" accompanied the History; they were each paid 3 livres tournois per day. ${ }^{24}$

We don't know any details about how the equestrian Louis XIV was packed, but a useful starting point may be found in the documentation related to the transport of Bernini's bust of Francesco D'Este to Modena, in its "machina." The bust was packed in a crate and covered by a mattress, which was placed on a small litter, and covered with waxed canvas. ${ }^{25}$ Bernini, who apparently oversaw the whole process quite closely, had devised the set-up when he sent his bust of Charles I to England. ${ }^{26}$ Giovanni Battista Ruggieri, d'Este's agent in Rome, had an aesthetic appreciation for the very packing materials - he describes the canvas as "very beautiful and very good." 27 The whole thing weighed in at more than 1,000 libbre (approx. $748 \mathrm{lbs}$ ) and was accompanied 
by one of Bernini's trusted servants, Cosimo Scarlatti. ${ }^{28}$ The weight and size of the equestrian Louis XIV would have made the challenge of packing it several orders of magnitude larger.

It seems to have been around August 1684 that Matthieu de La Teulière, then the head of the French Academy in Rome, suggested bringing Borzacchi to France to oversee the sculpture's arrival. ${ }^{29}$ We don't know exactly how Borzacchi's name got to de la Teulière, or if he had prior connections with the French. Perhaps he was nominated by Cardinal Alderano Cibo who, as we shall see, later promoted him to colleagues in France, or by Mattia de' Rossi, who was connected with the French Academy in Rome. ${ }^{30}$

The question of who was chosen to accompany sculptures in transit, and the possible social or professional rewards of such a task, is an interesting one. When Michelangelo sent his Risen Christ to Rome from Florence in 1521 it went with an assistant, Pietro Urbano. ${ }^{31}$ Urbano was a sculptor, and was charged with fixing any damages to the work once it had arrived. It was important to have someone capable of overseeing things on arrival, particularly if the work required any assembly. When Tacca's Philip III arrived in Spain there were complaints that the men who had come with the horse were not capable of erecting it, nor did they have the measurements to begin planning the base. ${ }^{32}$

In planning the shipment of the bust of Francesco d'Este, Bernini told Ruggieri that he "[would] find a man in the profession" to accompany it to Modena. ${ }^{33}$ Presumably by "the profession" he meant a sculptor. Yet, as we have seen, it was Scarlatti, who is described in another letter as someone "who takes care of many things in [Bernini's] house," who eventually accompanied the work..$^{34}$ By "the profession," did Bernini mean someone who specialized in moving and protecting substantial works of sculpture?

When the recipient of a work was high ranking, the possible rewards of successfully delivering a sculpture apparently went up. In 1613 Fra Roberto Dati campaigned to accompany and present Tacca's statues of Philip III and Henry IV. ${ }^{35}$ Dati argued that the task was an honorable one that should not be left to "some simple artisan." ${ }^{36}$ In the end it was Tacca's brother, Andrea, who went to Madrid with the Philip III, along with a team of assistants and servants. Andrea was granted 500 scudi once the work was installed. ${ }^{37}$ Overseeing the shipment of Bernini's equestrian Louis XIV to France must have been a daunting, but perhaps also an enticing task, as it held out the promise of potentially interacting with the French king himself, and making professional and financial gains.

The Louis XIV statue remained in Civitavecchia until at least October 21, $1684 .{ }^{38}$ At some point the statue disembarked in Genoa, with Borzacchi there to assist in the process ${ }^{39}$ By November 1 it was in Toulon, where Pierre Puget's Andromeda joined it on the boat; Puget's work was in the care of his son, who was also a sculptor and a painter, and who was paid 1,100 liveres tournois for the trip. ${ }^{40}$ The standard path for works travelling from Italy to Paris and Versailles was via river and overland. Works were set on the Rhone waterway and pulled by teams of horses on shore until Lyon. At Lyon cargo was transferred onto 
? weight and size of of packing it several ieu de La Teulière, bringing Borzacchi know exactly how mnections with the a Cibo who, as we 'y Mattia de Rossi,

dres in transit, and an interesting one. ence in 1521 it went , and was charged t was important to icularly if the work I Spain there were rere not capable of lanning the base. ${ }^{32}$ 'Este, Bernini told :o accompany it to rulptor. Yet, as we : as someone "who rally accompanied te who specialized

ossible rewards of I 1613 Fra Roberto is of Philip III and e that should not $s$ brother, Andrea, cam of assistants rk was installed. ${ }^{37}$ $\mathrm{V}$ to France must as it held out the nself, and making

t least October 21, th Borzacchi there vere Pierre Puget's re of his son, who res tournois for the aris and Versailles terway and pulled $s$ transferred onto ox-drawn carts, and taken overland to the town of Roanne and the Loire River. There cargo was again placed on a riverboat, taking the Briare canal to join the Seine at Saint-Mammè. ${ }^{41}$ This was the route apparently taken by Tacca's Henry $V^{42}$ The Louis XIV does not seem to have gone this way, as its next recorded port of call was Le Havre, France, where Pierre Cureau De la Chambre was dispatched in January 1685 to receive the statue, and the 24 crates-full of marbles, mosaics, and plaster casts of the Marcus Aureliusthat accompanied it. ${ }^{43}$ De la Chambre was joined in Le Havre by a sculptor, Jean Dedieu. Dedieu must have been there as an expert in the river transport of statues, as in 1684 he had overseen the move of the Venus of Arles (his hometown) to Paris. ${ }^{44}$ The only way for the Louis XIV to end up in Le Havre is if it went all the way around the Iberian peninsula, in a journey of just over two months. It is quite an astonishing trip, especially given the risks of attack by hostile navies and shipwreck.

Bernini's equestrian Louis XIV would finally arrive in Paris on March 10, $1685 .{ }^{45}$ It did not however remain there, instead moving on to Versailles, where its poor reception by Louis XIV is legendary. ${ }^{46}$ Louis apparently hated the work so much that on first sight he ordered it destroyed; he was eventually contented with Girardon's transformation of the sculpture into a Marcus Curtius ${ }^{47}$ (Figure 9.1). Borzacchi was on the French payroll and physically in Paris by December 20, 1684. ${ }^{48}$ Perhaps he went from Genoa overland to France to prepare for the equestrian's arrival; he would reunite with the work outside Paris, in Sèvres, to oversee its subsequent transfer overland to Versailles. ${ }^{49}$

While for Bernini the trip to France was largely a misadventure, for Borzacchi it seems to have precipitated a professional step up, at least temporarily. The first record we have of Borzacchi is from the archives of the Fabbrica of St. Peter's: in 1662 he was given nails for "il tiro di S. Agost[in]o" - presumably the nails were part of the equipment needed to pull the statue of Saint Augustine into its position on Bernini's Cathedra Petri. ${ }^{50}$ In a 1674 Fabbrica payment Borzacchi is referred to as a "muratore," a mason. ${ }^{51}$ Ten years later Parisian nunzio Angelo Ranuzzi identifies him as a "capomastro della Fabbrica di San Pietro" (master-mason of the Building Works of St. Peter's), suggesting that he had moved up the ranks of craftsmen. ${ }^{52}$ Borzacchi worked under Bernini in the latter half of the seventeenth century on various projects in St. Peter's, including the Chapel of the Holy Sacrament and the Constantine. ${ }^{53}$ Much of his work was quite mundane: in 1681 he was given materials to make a temporary shelter in St. Peter ${ }^{\prime} .^{54}$ At other moments he was engaged in producing scaffolding for Carlo Maratti for the decoration of the Chapel of the Presentation of the Virgin, and on another date he was given copper wires to hang two standards: an old one and one acquired more recently, which had been taken from the Turks in battle by the King of Poland and sent to the Pope as a gift. ${ }^{55}$ Borzacchi was engaged on all the major projects for St. Peter's, and was involved peripherally on some smaller ones as well, like Bernini's bust of Clement $X^{56}$ In the late $1660 \mathrm{~s}$ and early $1670 \mathrm{~s}$ Borzacchi worked on the installation of the Constantine. In the summer and 


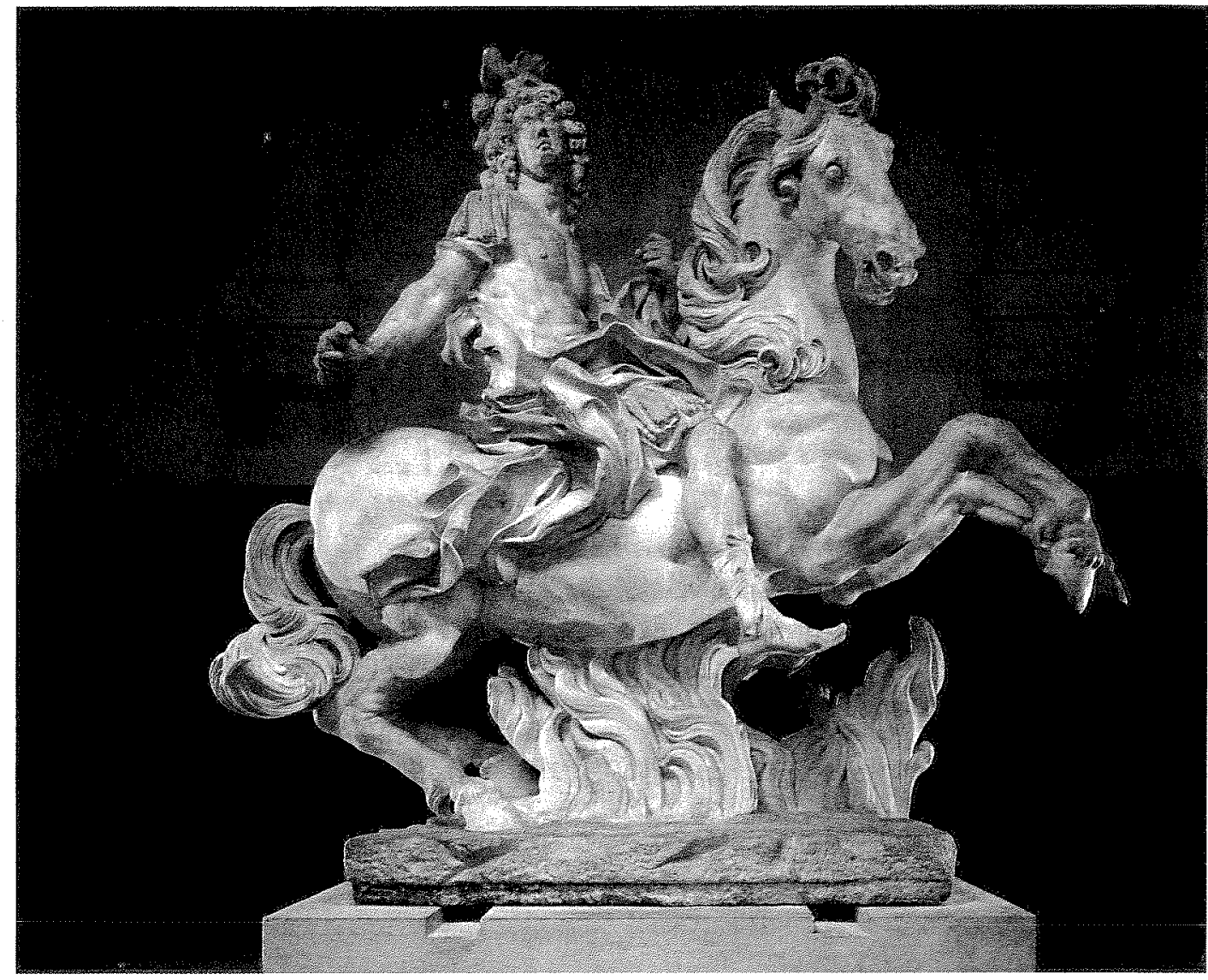

9.1 François

\section{Girardon}

(1628-1715),

after Gian

Lorenzo Bernini (1598-1680):

Equestrian Statue of Louis XIV as Marcus Curtius. Marble (Inv. INV1850 no. 9659). Photo: Gérard Blot. Chateaux de Versailles et de Trianon, Versailles, France. RMN-Grand Palais/Art Resource, NY early fall of 1668 the blocks of the pedestal and the marbles were hauled into place, while in November and December of the same year the walls around the statue were fixed--the holes left by scaffolding removed and the walls whitewashed and cleaned - and an enclosure set up in the expectation of its official unveiling. ${ }^{57}$ Borzacchi's presence at the construction sites was logged on a day-by-day basis. ${ }^{58}$

In France, Borzacchi's professional standing seems to have taken a step up. In French payment records and correspondence he is identified as a "Roman engineer" and an architect. 59 From December 1684 to July 1685 Borzacchi received roughly 330 livres toumois a month from the French king to accompany Bernini's horse to France. ${ }^{60}$ In August 1685 he received the same sum "for his subsistence" ("pour sa subsistence") - a daily allowance. ${ }^{61}$ We can contextualize his salary somewhat by comparing it with what he likely received from the Fabbrica and to the sums given to Bernini and his entourage on their trip. Capomastri masons of the Fabbrica likely received between 40 and 50 baiocchi per working day. ${ }^{62}$ In Rome there were roughly 274 working days in a year, or 23 per month, putting a capomastro's earnings at around 


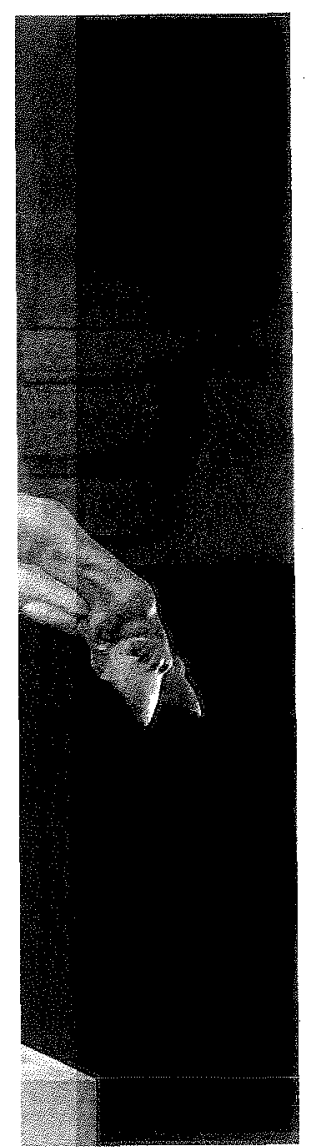

as were hauled into ir the walls around sved and the walls te expectation of its on sites was logged

have taken a step $\geq$ is identified as a 1684 to July 1685 om the French king e received the same ily allowance. ${ }^{61}$ We vith what he likely it and his entourage sceived between 40 ughly 274 working earnings at around
11.5 scudi per month (taking the upper end of the salary range). ${ }^{63}$ Borzacchi's monthly French salary of 330 livres was the equivalent of approximately 64 scudi-about 5.5 times his usual salary.

For his work in France, Mattia de' Rossi was paid 9,000 livres for a year (May 1666 to May 1667) - that is, 750 livres a month, or just over double what Borzacchi received. ${ }^{64}$ It would seem that for his skills and training Borzacchi was at a lower pay grade than De' Rossi, Bernini's closest assistant. De' Rossi's ability to command a higher salary may well have been thanks to his draftsmanship, as he created finished drawings of Bernini's projects. ${ }^{65}$ There is no evidence that Borzacchi had similar abilities, and he seems rather to have kept to technical and engineering tasks. As a capomastro at St. Peter's, managing a team of craftsmen would also have been among Borzacchi's capacities, and while in France Borzacchi had people working under his direction in moving the equestrian from Sèvres to Versailles. ${ }^{66}$

In October 1685, a large payment of 6,050 livres was ordered for Borzacchi, "par gratification" - as a bonus. ${ }^{67}$ He received 1,500 livres in France, and the rest on his arrival in Rome. ${ }^{68}$ On the king's behalf, Louvois also instructed de La Teulière that on the day of his return, Borzacchi was to receive a gold medal. ${ }^{69}$ When De' Rossi was assigned a bonus in 1666 it was 6,000 livres, the same as that indicated for Borzacchi; by comparison, one of Bernini's sculptural assistants, Giulio Cartari, was given only 1,200 livres. ${ }^{70}$ None of these sums came close, of course, to what Bernini received: 30,000 livres were sent to him in Rome before he even started his trip to France. ${ }^{71}$ Borzacchi's sizeable bonus is a significant sign of French recognition for the daunting task that he had successfully completed-having accompanied and acted as the guardian for the equestrian statue from its crating in the Vatican studio to its installment at Versailles. It was also apparently the last major expense that the French were prepared to pay for the horse; in June and November of 1685 Louvois twice wrote to de La Teulière to tell him to stop sending De' Rossi's designs for a grand setting for the horse to Paris, as the plans "were so expensive that they were of no use."72

Borzacchi's name comes up frequently in letters written between the numzio to France, Angelo Ranuzzi and Cardinal Alderano Cibo (1613-1700). Both were concerned to recommend him and his work to the French king, and took advantage of his trips between Paris and Rome to use him as a trusted courier. ${ }^{73}$ Cibo, who received a secret pension from Louis XIV starting in 1671, presented Borzacchi as a "trustworthy person." ${ }^{\prime 74}$ Borzacchi arrived in Paris with letters from the Cardinal that urged Ranuzzi to also "represent [Borzacchi's] abilities to the King, and the much that he contributed to the secure transport of the statue of his majesty."75 Ranuzzi must have done as Cibo urged, for a later letter from the nunzio reported that the king was pleased with Borzacchi's "zeal" and his service. "We get a glimpse of Borzacchi's prowess with the niceties of courtly culture in Pierre Cureau De la Chambre's Eloge du Cavalier Bernini. Borzacchi makes a witty, although anonymous, appearance, responding to potential criticism of the Louis XIV 
statue for the lack of reins with the "agreeable" observation that "[h]e who can rein in the whole world has no need to rein in this horse."

On his return trip to Rome, Borzacchi was also expected to courier writings related to current affairs, including materials against the ex-Jesuit Louis Maimbourg, who published his provocative Traité historique de létablissement et des prérogatives de l'église de Rome et de ses évêques (Historical Treatise on the Establishment and the Prerogatives of the Church of Rome and its Bishops) in $1685 .{ }^{78}$ Giovanni Battista Lauri, Ranuzzi's auditor, had also thought of sending a copy of Adrien Baillet's Jugemens des sçavans sur les principaux ouvrages des auteurs (Judgment of the Learned on the Principal Works of Authors) back to Rome with Borzacchi, but decided against it. ${ }^{79}$ Maimbourg and Baillet's texts were related to two of the papacy's main ongoing concerns in France: Gallic pretension to ecclesiastical independence and Jansenism. Presumably it was important to send such controversial materials, and whatever commentary may have accompanied them, with a "trustworthy person."

Borzacchi returned to Rome around August/September 1685 and went back to work at St. Peter's on the tomb of Clement $X$ under De' Rossi's direction. ${ }^{80}$ In another curiously faint echo of Bernini's career, which was troubled at the end of the artist's life over continued questions about the stability of his interventions at the crossing of St. Peter's, Borzacchi may have suffered some professional difficulties later on: there are a number of references to a roof over the bell tower "verso Campo Santo," which had to be torn down and rebuilt. ${ }^{81}$ However, he continued to work for the Fabbrica until months before his death on October 3, 1689.

A resident of the Borgo Pio, Borzacchi had no surviving children. His wife Cecilia Olimpia Spezia inherited his meager possessions, among them two large still life paintings of fish and fruit, eight small religious paintings, an unframed battle scene, 11 unnamed paintings, a head in gesso, and a wax model..$^{82}$ The head and model are tantalizing and frustratingly unidentifiedperhaps Borzacchi was in possession of some of the models Bernini made for his studio's use? The brief royal recognition that Borzacchi enjoyed in France, made material in the form of the bonus and gold medal, do not seem to have translated into a professional promotion back in Rome. An anonymous "Roman engineer" to Cureau de la Chambre, Borzacchi died in Rome a modest craftsman in the Vatican's employ, his feat in successfully overseeing the transport of Bernini's Louis XIV apparently forgotten.

Notes

My sincerest thanks to Maria Grazia d'Amelio, David Boffa, and Anna Seidel for their insights as this essay developed, and to the staff of the Archivio della Fabbrica di San Pietro for their assistance in my research there.

1 Archivio della Fabbrica di San Pietro (hereforward AFSP), Armadio 27, B, 381 (Uscita di munizioni 1680-85). "A di 24 Febraro 1684 a Jacomo Bozzache Caviche 
on that "[h]e who ie." 77

to courier writings re ex-Jesuit Louis ce de l'établissement rical Treatise on the $s$ Bishops) in 1685.78 t of sending a copy uorages des auteurs rack to Rome with ; texts were related Gallic pretension , it was important nentary may have

685 and went back Rossi's direction. ${ }^{80}$ $h$ was troubled at the stability of his ave suffered some zerences to a roof be torn down and ntil months before

children. His wife among them two ious paintings, an gesso, and a wax gly unidentified $s$ Bernini made for enjoyed in France, 1 , do not seem to ie. An anonymous i died in Rome a ssfully overseeing

and Anna Seidel te Archivio della e.

madio 27, B, 381 o Bozzache Caviche di ferro che li devano servire per l'armatura che detto fa Per il cavallo e statua della Re di francia che detto Jacomo Bozzache le deve Paghare alla R[everen]da fabricha di S. Pietro così per d'ordine di Monsegniore Illustrissimo Vespiniano segretario et econimo della Reverenda Fabricha di S. Pietro che dette Cavichie e zepe anno peso $t$. [tutto] asieme libre caviche in 10 libre cento cinque." I have left the orthography of the documents from the AFSP as they are. For terminology see: Angela Marino, Sapere e saper fare nella fabbrica di San Pietro. Castelli e ponti di maestro Niccola Zabaglia 1743 (Rome: Gangemi, 2008), 152, 134. Borzacchi's name appears in documents in a variety of different forms, including Borzachi, Borzachy, Borzache and Borzatti. In his will he is named as "Borzacchius"; I have thus used "Borzacchi."

2 As Maarten Delbeke has argued, the tendency in Bernini scholarship is toward "the merging of Bernini's art with his persona and of the persona with his age." Maarten Delbeke, The Art of Religion: Sforza Pallavicino and Art Theory in Bernini's Rome (Farnham, UK: Ashgate, 2012), 2-3.

3 Franco Borsi, ed., Gian Lorenzo Bernini: il testamento, la casa, la raccolta dei beni (Florence: Alinea, 1981).

4 See note 71 (Louvois's letters to Matthieu de La Teulière about Mattia de' Rossi's designs).

5 On the chronology of the statue's production see Rudolf Wittkower, "The Vicissitudes of a Dynastic Monument: Bernini's Equestrian Statue of Louis XIV," in De artibus opuscula XL: Essays in Honor of Erwin Panofsky, ed. Millard Meiss (New York: New York University Press, 1961), 497-531.

6 Wittkower, "The Vicissitudes," 529-30, doc. 74.

7 Wittkower, "The Vicissitudes," 529-30, docs 74 and 75.

8 Wittkower, "The Vicissitudes," 530, doc. 76.

9 Daniela del Pesco, "Il vicerè del Carpio e la statua equestre di Luigi XIV di Bernini,". in Studi sul Barocco romano. Scritti in onore di Maurizio Fagiolo dell'Arco (Milan: Ministero per i Beni e le Attività Culturali, 2004), 317.

10 Del Pesco, "Il vicerè," 317.

11 “... n'estant pas une petite affaire de mette une si grande machine dans la barque ..." Thierry Sarmant and Raphaël Masson, eds, Architecture et beaux-arts à l'apogée du règne de Louis XIV: édition critique de la correspondance du Marquis de Louvois, Surintendant des Bâtiments du Roi, Arts et Manufactures de France, 1683-1691, conservée au Service Historique de la Défense (Paris: CTHS, 2007), vol. 1, 170-71, letter 493. Letter to Matthieu de La Teulière, Chambord, September 30, 1684. "Les cables que vous aves fait faire pour la statue équestre estant inutiles, je croy que vous devriez les faire embarquer sur le vaisseau du roy afin que l'on puisse s'en servir pour la débarquer à Paris."

12 Irving Lavin, "Bernini's Image of the Sun King," in Past-Present. Essays on Historicism in Art from Donatello to Picasso (Berkeley: University of California Press, 1993), 584, n. 65.

13 According to Lavin's calculations, the Louis XIV must have been carved from a block $19.98 \mathrm{~m}^{3}$; quite a bit larger than the Constantine, which Domenico Bernini reports was carved from a marble block of 30 carretate, or $30 \times 362.43 \mathrm{~cm}^{3}=10.87$ $\mathrm{m}^{3}$. Lavin, "Bernini's Image of the Sun King," 585. 
14 AFSP, Registro delle robe vendute, arm. 27, rip. B, vol. 377, f. 95: "due casse di ferro quanto le 4 girelle di metallo, servite solamente a Ripa per calare e imbarcare la statua." I thank Maria Grazia D'Amelio for sharing this document with me.

Maria Grazia d'Amelio, private correspondence.

Kelley Helmstutler Di Dio, forthcoming.

17 On the statue and the first stages of transport see Cristiano Giometti, Domenico Guidi, 1625-1701. Uno scultore barocco di fama europea (Rome: "L'Erma" di Bretschneider, 2010), 229-34, esp. 230-31.

19 Anatole de Montaiglon, Correspondance des directeurs de l'Académie de France à Rome avec les surintendants des bâtiments (Paris: Charavay Frères, 1887), vol. 1, 155, letter 261, from de La Teulière to Louvois. Giometti, Domenico Guidi, 133.

20 Montaiglon, Correspondance, vol. 1, 155, letter 261. "..., ce que j'ay creu ne pouvoir pas luy refuser, parce que, s'il estoit arrivé quelque accidant à son groupe, il s'en serait pris à moy.".

21 Montaiglon, Correspondance, vol. 1, 155, letter 261.

22 Montaiglon, Correspondance, vol. 1, 155, letter 261. ".. et qui ne peuvent estre renversés sur la fluste qu'après le groupe, aussy bien que le tableau, parce que la caisse du groupe bouchait le passage."

23 "... je ne croy pas qu'il y ait des gens dans le monde plus intraitables que les gens de ce pays dans des occasions où ils croient que l'on ne saurait se passer d'eux ...." Montaiglon, Correspondance, vol. 1, 155, letter 261.

24 Guidi's statue left Rome by April 9, 1686 and arrived in Paris by August of the same year. Lorenz Seelig, "Zu Domenico Guidis gruppe 'Die Geschichte Zeichnet die taten Ludwigs XIV. auf'," Jahrbuch der Hamburger Kunstsammlungen 17 (1972): 88-9. Jules Guiffrey, Comptes des bâtiments du roi sous le règne de Louis XIV, vol. 2 (Paris: Imprimerie nationale, 1887), column 953. Giometti, Donenico Guidi, 231.

25 Giorgia Mancini, "Appendice documentaria" in Irving Lavin, Bernini e l'immagine del principe cristiano ideale (Modena: Franco Cosimo Panini, 1998), 55.

26 Mancini, "Appendice," 63, doc. 35.

27 "... bellissima, e buonissima ... ." Mancini, "Appendice," 65, doc. 41.

28 Mancini, "Appendice," 55.

29 Architecture et beaux-arts, vol. 1, 170-71, letter 493. Letter to de La Teulière, Chambord, September 30, 1684. "Mandez-moy un peu à quoy vous croyez que l'on pourroit appliquer en ce pays-ci le nommé Borzalti [sic], ce que vous m'en dites estant si général que je ne puis comprendre de quoy l'on le pourroit charger si on le vouloit retenir en France. Expliquez-vous donc plus clairement." De La Teuilière was sent to Rome on October 18, 1683 "to serve the king." Montaiglon, Correspondance, vol. 1, 128, entry 237. Unfortunately de La Teuilière's correspondence is only collected from September 1684. Montaiglon, Correspondance, vol. 1, 144.

30 Cibo was maggiordomo pontificiale under Innocent $X$, which gave him the power to select artists for papal projects. Cibo also had quite close connections with Bernini. Fabrizio Federici, "Un giovane prelato, Bernini e Borromini: il primo soggiorno romano di Alderano Cybo," Ricerche di Storia dell' Arte 79 (2003): 96-100. 
f. 95: "due casse ipa per calare e aring this document

Giometti, Domenico : "L'Erma" di

adémie de France à ires, 1887), vol. 1, 155, co Guidi, 133.

le j'ay creu ne pouvoir tà son groupe, il s'en

i ne peuvent estre tableau, parce que la

traitables que les e saurait se passer 1.

is by August of the e Geschichte Zeichnet ;ammlungen 17 (1972): 3 de Louis XIV, vol. 2 Jomenico Guidi, 231.

$n$, Bernini e l'immagine 1.998), 55.

;, doc. 41.

\section{łe La Teulière,} oy vous croyez [sic], ce que de quoy l'on le $z$-vous donc plus $8,1683^{\text {" to serve the }}$ fortunately de La r 1684. Montaiglon,

gave him the power connections with rromini: il primo Irte 79 (2003): 96-100.
31 William E. Wallace, "Miscellanea Curiositae Michelangelae: A Steep Tariff, a Half Dozen Horses, and Yards of 'Taffeta," Renaissance Quarterly 47 (1994): 332.

32 Helmstutler Di Dio, forthcoming. Letter of September 15, 1616, Orso d'Elci to the court in Florence.

33 Mancini, "Appendice," 63, doc. 35.

34 Mancini, "Appendice," 64, doc 41.

35 Helmstutler Di Dio, forthcoming.

36 Helmstutler Di Dio, forthcoming.

37 Helmstutler Di Dio, forthcoming.

38 Wittkower, "The Vicissitudes," 77.

39. Guiffrey, Comptes des bâtiments, vol. 2, column 722."28 janvier-22 juillet (1685): au s.r Borzachi, ingénieur romain, pour six mois de ses appointements, pour avoir conduit la statue de marbre de S. M. à cheval, de Rome en France, et pour frais de débarquement de ladite statue à Gênes, 2,020, l."

40 Jacques Vanuxem, "Quelques temoignages français sur le Bernin e son art-L'Abbe de la Chambre," in Actes des Journées Internationales d'Étude du Baroque (Toulouse: Association des Publications de la Faculté des Lettres et Sciences Humaines, Toulouse avec le concours du Centre National de la Recherche Scientifique, 1965), 163. Guiffrey, Comptes, col. 666. Puget "fils" - François - was paid on July 15. For comparison, Pierre Puget was paid 15,000 livres toumois for the sculpture.

41 Dominique Séréna-Allier, Louis XIV et la Vénus d'Arles. La plus belle femme de mon royatme (Arles: Actes Sud, 2013), 44.

42 Helmstutler Di Dio, forthcoming.

43 Architecture et beaux-arts ... vol. 2, 20, letter 669. Letter to Jean-Louis Habert de Montmort, in charge of the port at Le Havre, Versailles, January 31, 1685. "Le sieur de La Chambre, qui vous rendra cette lettre, estant envoyé pour prendre soin de faire descharger la statue équestre du roy, je vous suplie de luy donner toutte l'assistance dont il vous requérera et, en cas qu'il y ayt besoin d'argent pour l'exécution des ordres qu'il a, de luy en faire fournir, dont j'auray soin de vous faire rembourser icy à qui vous désirerez sur le premier advis que vous maurez donné de ce que vous aurez fait payer audit sieur de La Chambre." Architecture et beaux-arts ... vol. 2, 50, letter 750. Letter to Lambert Clerx, banker, Versailles, February 15, 1685. "J'ay receu vostre lettre du 12e de ce mois. Le passeport que vous demandez pour la statue équestre du roy et les quatre-vingtquatre caisses qui l'acompagnent a esté remis au sieur de La Chambre, lequel a esté envoyé par ordre de S. M. pour les faire conduire a Paris, mais, comme outre le nombre des caisses susdites, il en a encore deux qui on esté chargées en Provence, pour lesquelles il a esté expédié un passeport particulier que l'on doit vous avoir adressé, mandez-moy si vous l'avez receu et si vous envoyé à vostre correspondant." On the contents of the crates, see A. Bertolotti, Artisti francesi in Roma nei secoli XV, XVI e XVII:

44 Guiffrey, Comptes, vol. 2, col. 759. "8 avril: à Dedieu, sculptor, pour le voyage qu'il a fait au Havre pour débarquer et conduire la statue équestre du Roy du Havre è Sève ... 280 (livres tournois)." Séréna-Allier, Louis XIV et la Vénus d'Arles, $43-5$. 
45 Wittkower, "The Vicissitudes," 530 , doc. 78.

46 See Robert W. Berger, "Bernini's Louis XIV Equestrian, a Closer Examination of its Fortunes at Versailles," The Art Bulletin 63 (1981): 232-48.

47 See Berger, "Bernini's Louis XIV Equestrian."

48 Guiffrey, Comptes, vol. 2, col. 565, col. 722. "24 décembre (1684): au s.r De Borzachi, ingénieur romain, qui a conduit la grande statue de marbre du Roy à cheval, de Rome en France, pour sa subsistance pendant un mois qui finira le 17 du mois prochain, 330 1." Bruno Neveu, ed., Correspondance du Nonce en France Angelo Ranuzzi (1683-1689) (Rome: École français de Rome, 1973), vol. 1, 459, letter 1045. Dispatch of Ranuzzi from Paris to Cardinal [Alderano] Cybo on December 20,1684, n. 1045. "È giunto qua il Borsachi, capomastro della Fabbrica di San Pietro, e mi ha resa la benignissima lettera di V.E. che m'impone d'assisterlo nelle sue occorrenze e di rappresentare anco al re la di lui habilità e il molto che ha contribuito al sicuro trasporto della statua di S. M.tà ..."

49 Guiffrey, Comptes, vol. 2, col. 758. "12 septembre-14 octobre (1685): au s.r Fossier, pour estre employé suivant le réquisitoire du sieur De La Chapelle-Bessé, au paiement des ouvriers qui travaillent sous le sieur Borzachi à conduire la statue équestre de S. M. de Sève à Versailles, depuis le 27 aoust jusqu'au 28 septembre, $1,1731.9$ s. $6 \mathrm{~d} . "$

50 Roberto Battaglia, La cattedra Berniniana di San Pietro (Rome: Reale Istituto di Studi Romani, 1943), 199. "Feb. 21 1662. Chiodi lb. vintisei per il tiro di S. Agost.o."

51 AFSP, Liste e giustificazioni 1674, II piano, serie 4, vol. 15. XLIV c. 295. "Dalli 14 X[m]bre 1673 e t[utt]o li 23 Giugno 1674 Misura e stima ... comprensovi nella $\mathrm{p}$ [rese]nte stima un Conto d'altre partite de lavori diversi fatti per diversi servitij della R[everend]a fabrica di S. Pietro, fatto il tutto da m[astr]o Jacomo Borzatti muratore, misurati e stimati da noi sottoscritti ministri di essa R[everenda] fabrica come distintamente segue a partita per partita."

52 Neveu, ed., Correspondance, vol. 1, 459. See note 48 above. On the role and responsibilities of a capomaestro see C. Paola Scavizzi, Edilizia nei secoli XVII e XVIII a Roma. Ricerca per una storia delle tecniche (Rome: Ministro per i beni culturali e ambientali, 1983), 63-5. One of the requirements mentioned by Scavizzi is that a capomastro have his own munitions (in the sense of equipment or stores), as Borzacchi did. AFSP, Arm. 27, B, 365, Libro della munizioni 166882,40 . "1685 Havere a di 3 Aprile n.o uno trovato in mano di Giacomo Borzatti (dà renderne conto) nella sua monitione vicino la stanza di S. Lorenzo Berti sopra San Sisto, come per Inventario fatto il corr.e giorno n.o 1:83."

53 For work on the Altar of the Holy Sacrament (as "m[astr]o Jacomo Borzatti"): Valentino Martinelli, ed., L'ultimo Bemini: 1665-1680; muovi argomenti, documenti e immagini (Rome: Edizioni Quasar, 1996), 241. On the Constantine see below, note 57.

54 AFSP, Armadio 27, B, 381 (Uscita di munizioni 1680-85), [5r]. "A di 4 Aprile 1681 a Jacomo Bozzachi Chiodi per la capanna fatta in S. Pietro libre sei." The "Uscite di munizioni." contain records of materials given out by the Fabbrica, with their value by weight. They do not therefore tell us anything about how much Borzacchi was paid for his work.

55 AFSP, Armadio 27, B, 381 (Uscita di munizioni 1680-85), 5v. "A dì 13 maggio 1681 a Jacomo Borzache chiodi per fare il ponte alla Capella dello Presentazione che deve servire per il Sig. Carlo marata che deve fare li cartone [libre] 6." 
oser Examination of

84): au s.r De de marbre du Roy in mois qui finira tance du Nonce en Rome, 1973), vol. al [Alderano] Cybo pomastro della li V.E. che $\mathrm{m}^{\prime}$ impone e la di lui habilità e il i. M.tà ..."

(1685): au s.r Fossier, hapelle-Bessé, au à conduire la statue iqu'au 28 septembre,

Reale Istituto di Studi o di S. Agost.o."

LIV c. 295. "Dalli 14 omprensovi nella tti per diversi servitij ']o Jacomo Borzatti sa R[everenda]

$\mathrm{n}$ the role and a nei secoli XVII nistro per $i$ beni mentioned by sense of equipment lla munizioni 1668li Giacomo Borzatti S. Lorenzo Berti sopra "

acomo Borzatti"): argomenti, documentie intine see below,

]. "A di 4 Aprile 1681 bre sei." The "Uscite Fabbrica, with rabout how much

"A di 13 maggio dello Presentazione tone [libre] 6."
AFSP, Armadio 27, B, 381 (Uscita di munizioni 1680-85), 12v. "A di 12 ottobre 1683 a Jacomo Borzache filo di Rame che deve servire per atachare lo sternardo vechio et lo stenardo venuto ultimamente mandatto dal Re di Polonia Preso in bataglia alli Turchi [proposed: libre] 3 tre."

56 AFSP, Arm. 27, B, 365, Libro della munizioni 1668-82, 154. 1676 "E a di 4 detto [maggio] a Jac.o Borzatti per fare un Posto dove lavora il S. Cav.re Bernini per il ritratto di Papa Clement X. bol__ 1791 ___ libre 6."

57 AFSP, Arm. 27, B, 358, Libro mastro del Fattore 1667-84, unnumbered. Between August 27 and September 29, 1668, Borzacchi was paid "... di tirare e metere in opra li conci del Piedestallo del Costantino ...," between June 11 and July 14, 1669 for having "... murare e metere in opra li marmi del Piedestalo del Costantino ...," and between November and December for "... murare li buchi di ponti et inbianchare e pulire li muri atorno la statua del Costantino e difare lo stechatto per la domen[ica] delavento che si scopri ...." He was paid again in 1672 to "... fare la stricho per lo matonato tagliato sotto il Piedestallo del Costantino."

58 See for example AFSP, Arm. 27, B, 358, Libro mastro del Fattore 1667-84.

59 Guiffrey, Comptes, vol. 2, col. 565, c. 722. See note 39 and note 48. On Borzacchi as an "architect": Neveu, ed. Correspondance, vol. 1, 499, letter 1201.

60 See note 48 .

61 Guiffrey, Comptes, col. 565.

62 Scavizzi, Edilizia, 64.

63 Scavizzi, Edilizia, 65. That would be roughly 138 scudi per year, which is probably slightly high. In studying painters' earnings, Spear and Sohm assumed a working year of 250 days. Their estimations of the earnings of painters who worked for a daily wage are in the same range of what I have estimated here for Borzacchi. Borzacchi and his wife (they had no children, or none who lived to adulthood) were thus likely above the "subsistence level" of 20 scudi per year per person, but my estimations do not take into account professional expenses or personal misfortunes (sick days, injuries). Richard Spear and Philip Sohm, eds, Painting for Profit. The Economic Lives of Seventeenth-Century Italian Painters (New Haven and London: Yale University Press, 2010), 21-2, 36. For comparison, Bernini's highest paid position was architect of the Fabbrica of St. Peter's, at a salary of 200 scudi per year. Together, Bernini's various positions brought him 744 scudi per year. See Scavizzi, Edilizia, 66. All currency calculations are based on Angelo Martini, Manuale di metrologia ossia Misure, pesi e monete in uso aitualmente anticamente presso tutti i popoli (Rome: Ed. E.R.A., 1976). My thanks to Michael Portt for help with the numbers.

64 Wittkower, "The Vicissitudes," 517.

65 De' Rossi's role is mentioned many times by Chantelou. See Daniela del Pesco, Bernini in Francia. Paul de Chantelou e il 'Journal de voyage du cavalier bernin en france' (Naples: Electa, 2007).

66 Guiffrey, Comptes, vol. 2, col. 758. See note 49.

67 Guiffrey, Comptes, col 597. "16 octobre. dud s.r vu Metz, $6000^{\text {th }}$ pour délivrer au s.r Borzachy, ingénieur romain, par gratification, et $50^{\text {th }}$ pour les taxations ... 6050"t." 
68 Guiffrey, Comptes, vol. 2, col. 668. "Au s.r Borzachi, ingénieur romain, 1500" en déduction de $600^{\text {tt }}$ [sic] que S. M. luy a accordes par gratification ... . 1500", " Architecture et beaux-arts, vol. 2, 474, letter 2123. Letter to Mathieu de La Teulière, October 17, 1685. "Vous verrez arriver à Rome peu de jours après cette lettre le sieur Borzachy, que j'ay chargé d'une autre lettre pour vous, par laquelle je vous mande que, le roy luy ayant accordé six mil livres en considération du service qu'il a rendu icy, je luy en ay fait payer 1,500 livres, qu'il a désiré toucher en ce lieu et que vous debves luy faire remettre à Rome les quatre mil cinq cens livres restans. Pour vous donner moyen d'y satisfaire, je vous enjoye une lettre de change de six cens pistoles, et cous verrez par la lettre dont je l'ay chargé qu'outre cet argent, S.M. m'a aussy comandé de luy donner une médaille d'or à laquelle on travaille, que je vous adresseray au premier jour pour la luy donner. Vous aurés soin d'employer en recepte dans vos compte les 6,600 livres de ladite lettre de change et en despense les 4,500 livres que vous donnerés audit Borsachi."

$69^{\circ}$ See note 68.

70 Wittkower, "The Vicissitudes," 517.

71 Wittkower, "The Vicissitudes," 517. Bernini's heirs would however fight to receive money owed to their father by the French crown for many years after the artist's death.

72 Architecture et beaux-arts, vol. 2, 299-300, letter 1554. Letter to de La Teulière, June 25, 1685. "Quand j'auray veu le dessein du sieur Matthia de Rossy, le roy jugera s'il mérite plus que la médaille que je vous ay envoyée pour luy donner; mais je dois vous dire qu'une autre fois il ne faut pas faire des desseins qui coutent si cher lorsqu'ils ne servent de rien." Architecture et beaux-arts, vol. 2, 499, letter 2206. Letter to de La Teulière, November 6, 1685. "J'ay receu vostre lettre du $16 \mathrm{e}$ de ce mois [sic]. Pour respondre à ce que vous me mandez sur le dessein du sieur Mathia Rossi, je ne puis m'empescher de vous dire que cet ouvrage est si inutile que j'estime que la médaille et tout ce que l'on luy pourroit donner est de l'argent perdu. Ainsy, vous debves vous contenter de luy donner ladite médaille."

73 Neveu, ed., Correspondance, vol. 1, 461, letter 1054; 499, letter 1201; 508, letter 1238; 545 , letter 1360; 576 , letter 1482; 605 letter 1589; 608-9, letter 1598; 633 and letter 1678. Neveu unfortunately does not publish the complete texts of the many of the letters, instead he short summaries of their contents; I have not been able to consult the originals and am working from Neveu's indications.

74 Neveu, ed., Correspondance, vol. 1, 622, letter 1645. Cibo to Lauri. Rome, November 13, 1685. On Cibo see: Enrico Stumpo, "Cibo, Alderano" in Dizionario Biografico degli Italiani, vol. 25, 1981. http://www.treccani.it/enciclopedia/ alderano-cibo_(Dizionario-Biografico)/. Federici, "Un giovane prelato," 52.

75 Neveu, ed., Correspondance, vol. 1, 459, letter 1045.

76 Neveu, ed., Correspondance, vol. 1, 601, letter 1578. Ranuzzi to Cibo. October 15, 1685. Architecture et beaux-arts, vol. 2, 472, letter 2118. Letter to Charles Colbert de Croissy, Minister and Secretary of Foreign Affairs, October 16, 1685. "Ce mot est pour vous faire souvenir de prendre l'ordre du roy pour escrire à M. le duc d'Estrées de tesmoigner à $M$. le cardinal Cibo que le roy a esté fort satisfait du service que luy a rendu icy le sieur Borsachi et que le roi remercie Mons. le cardinal Cibo de le luy avoir envoyé." 
"romain, $1500^{\text {k }} \mathrm{en}$ tion ... . 1500"t." thieu de La Teulière, après cette lettre le par laquelle je vous áration du service ésiré toucher en tre mil cing cens $s$ enjoye une lettre nt je l'ay chargé une médaille d'or à pour la luy donner. 6,600 livres de us donnerés audit

owever fight to many years after the

s de La Teulière, June Rossy, le roy jugera - luy donner; mais sseins qui coûtent

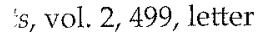
vostre lettre du $16 \mathrm{e}$ ur le dessein du sieur ruvrage est si inutile donner est de l'argent lite médaille."

1201; 508, letter 1238; 1598; 633 and letter xts of the many of ave not been able to ions.

auri. Rome, Jerano" in Dizionario nciclopedia/ ne prelato," 52.

o Cibo. October 15 to Charles Colbert ver 16, 1685. "Ce pour escrire à $M$. le y a esté fort satisfait remercie Mons. le
77 Pierre Cureau de la Chambre, Eloge du Cavalier Bernin (S.I. n.d.), 22-4. Stanislao Fraschetti first recognized Borzacchi as the speaker. Stanislao Fraschetti, Il Bernini: la sua vita, la sua opera, il suo tempo (Milan: Hoepli, 1900), 361.

78 Nicholas Weber, "Louis Maimbourg," in The Catholic Encyclopedia (New York: Robert Appleton Company, 1910). Retrieved July 26, 2014 from New Advent: http:/WwW.newadvent.org/cathen/09540a.htm.

79 Neveu, ed., Correspondance, vol. 1, 608-9, letter 1598. Lauri to Cibo. Paris, October 22,1685 . Possibly for security reasons, but it also may not have been printed in time.

80 Borzacchi's stipend from the French king covered July and August of 1685, and by September 1685 he was once again employed by the AFSP. Arne Karsten and Matthias Pabsch, "Das Grabmal Clemens X. Altieri," Städel-Jahrbuch 17 (2000): 300. Karsten and Pabsch refer to him as "Borzatti."

81 AFSP, Arm. 27, C, 390, Uscita delle munizioni, 1685-1713. unpaginated. "no. 362 [margin: in debito al Borzatti] A d. 58 bre A Mre. Ane. Mre. Chiodi da settanta libre una per appuntellare il tetto che si deve demolire, fatto da Giac. Borzatti / Chiodi da sett.a libbre." "no. 374 [margin: in debito al Borzatti] A di 99 mbre A Mod. And. Mre Chiodi da piano/piane libre quattro e mezza per inchiodarelo piano che si è rifatto di nuovo, quale haveva fatto Giac.o Borzatti sopra il Campanile verso Campo Santo per farli buoni alla fab / Chiodi da piano libre 41." "no. 376 A di 129 mbre A Mre. Ane. Mre. piano di selio numero Cinquanta per metterlo al tetto, che si è rifatto di nuovo, quale haveva fatto giac.o Borzatti sopra il Campanile verso Campo Santo per farlo buone detto Borzatti alla Revda fabrica / Piane di selio numero 50." "no. 437 [margin: in debito al Borzatti] a di 23 Maggio 1689 a Mre. Ant.o Mre. chiodi da piano libre quattro per inchiodare un tetto di haveva fatto Gia.co Borzatti sopra il Campanile co. Palazzo rifatto di nuovo per [danno?] debito al med. Borzatti / Chiodi da piano libre 4." On Bernini's misfortunes see: Tod Marder, "A Finger Bath in Rosewater: Cracks in Bernini's Reputation," Sankt Peter in Rome 1506-2006, Beiträge der internationalen Tagung vom 22-25. Februar 2006 in Bonn, ed. Georg Satzinger and Sebastian Schütze (Munich: Hirmer, 2008), 427-34.

82 Archivio Capitolino, Notai AC Petrocchius 5900, 196r-206v. Jacobus Borzacchius, October 3, 1689, 200r-201r. 